\title{
A Teaspoon of Earth and Sea
}

\author{
by Dina Nayeri
}

Published by Penguin Group, 2013, 466 pages.

\section{Reviewed by}

David Saenz (david.saenz@stonybrook.edu), Graduate Student in the Higher Education Administration Program, Stony Brook University

In A Teaspoon of Earth and Sea, Nayeri crafts an exquisite tale that intertwines parallel stories occurring in America and post-revolutionary Iran. The stories are told mainly from the point of view of Saba Hafezi, the novel's protagonist. She is a rebellious woman who is struggling to find her place in Iran, while dreaming of living in America. In addition, there are some chapters written from the point of view of three women who serve as Saba's surrogate mothers, which adds richness to the story. These voices add multiple female perspectives, deepen the reader's knowledge of life in Nayeri's Iran, and offer counterpoints to Saba's improbable stories.

A great mystery ties the multiple narratives together: the inexplicable disappearance of Mahtab, Saba's twin sister, and Bahareh Hafezi, Saba's mother. Although Saba decided at an early age that Mahtab and Bahareh fled Iran to live in America, other characters in the story hint toward a darker truth. The readers are taken on a journey from Saba's infancy to adulthood, living her struggles and absorbing her stories of Mabtab, all the while wondering and forming their own hypotheses about the real conditions behind these characters' disappearance.

Saba grew up in a small village in Iran, while her father tried his best to save himself and his remaining daughter from a sinister fate, since the family committed the purported sin of being Christian in the newly formed Islamic republic. Saba maintained an addiction to American media, buying contraband shows and music tapes, while memorizing list after list of English words to impress her mother and sister when they would finally meet in America. Saba is being brought up by three different local women who attempt to fill the void left by her missing mother and her emotionally absent father.

In Saba's mind, she imagines a great life for her sister from what she knows of America and sitcom style narrative to evade the problems and tribulations that she faces in Iran. She is forced to wear a hijab, to behave like a proper Muslim, and entertain the mullahs that frequently visit their home. At the same time, Saba manages to enjoy certain luxuries such as homemade alcohol, marijuana, and the company of her two best friends, the beautiful Ponneh and the charming Reza. As the trio grows up, both Ponneh and Saba develop romantic feelings toward Reza and begin a subtle competition for his affection. They become a trio that enjoys 
spending time together, drinking and smoking, and generally enjoying the luxuries of youth, while hoping that they never have to grow up and face the world that might break them apart.

When Saba and Reza are discovered giving each other a light peck on the lips, she is forced to choose either to be married to an older, wealthy Muslim man (Abbas) or go to university in Tehran. She decides to save herself for an American university, one just like Mahtab is attending in her stories. Besides, Tehran University has little to offer Saba after the revolution stripped much of what could be taught to her. Saba again imagines a story of the strong Mahtab and how she rejected someone's marriage proposal and decided to concentrate on her studies; on the other hand, poor Saba has to marry Abbas. After her marriage, Saba attempts to maintain her previous bachelorette life, visiting her father's house and reuniting the trio as often as possible. She sees her husband's wealth as her ticket to freedom in America once she becomes a widow.

Saba's two biggest challenges, besides her mother and sister's disappearance, come both at the hand of the strict Islamic regime that has taken over Iran. First, her best friend, Ponneh, is savagely beaten by a pasdar because she made the mistake of wearing red high heels underneath her pious chador. The brutal beating left physical and psychological scars on Ponneh, forever radicalizing her. Saba faced her own share of violence when her husband hired two women to take away her virginity, thus ensuring that his manhood would remain unquestioned. The crude procedure left Saba with irregular periods and the threat of never being able to carry a pregnancy to term.

Mounting piles of evidence against her hazy memories make Saba realize that her twin sister, Mahtab, died the night the pair decided to go for a night swim in the ocean. Her mother, in the chaos of the situation, was accused of obstructing the search for the girls and became directly responsible for Mahtab's death. One fateful day at the airport, Saba ran after someone she thought was her sister, and in the chaos, her mother disappeared. The most likely outcome is that Bahareh was found by the pasdars and likely executed on site, since there are no records of her incarceration anywhere. It becomes clear to Saba that the stories she created about Mahtab are her yearning for a different life, for the freedom that, in her eyes, only America can provide.

Widowhood comes to Saba, but her inheritance is threatened by the sudden appearance of a possible brother-in-law. Saba is able to liquidate some of her assets and begins to plan her escape to America. As a widow, Saba begins a secret romance with her childhood friend, Reza. Ponneh has become more radical after witnessing the execution of a friend. Saba, however, realizes that her happiness with Reza is temporary and that they truly do not belong together. Reza loves Ponneh. Saba moves quickly and secretively to secure a visa to America. She says goodbye to her loved ones and embarks toward a new life in America. At the end, Saba realizes that the fantastic tales of Mahtab in America were simply her own wishes for freedom. Saba finally comprehends that her purpose in life, her true happiness, will come when she can become an independent woman, a journalist that will be able to help Ponneh's rebellion through the power of the media, 
exposing the atrocities committed by the regime in Iran.

Nayeri's novel deals with many topics: adversity, transitions, pursuing one's dreams, the differences between cultures and norms, and, most importantly, having the courage to do what one believes to be right despite opposition and religious persecution. The novel also challenges heteronormative views through Ponneh's lover. These topics make this book a valuable text for incoming freshman students to read. The narrative gives students a glimpse of the culture of a different country and shows them how others have dealt with adversity and life's transitions. The book also offers important insight into the Iranian revolution and the effects that this uprising had on the government and people of Iran.

Although A Teaspoon of Earth and Sea can serve as a generative educational tool for incoming freshman students, there are certain events that transpire in it that should be approached carefully in the classroom. In particular, there are a few scenes of violence against women and even the intentions of a pasdar to rape Ponneh. These topics are difficult to deal with, and some students might be especially susceptible to being affected by them. I would recommend having the advice of mental health professionals as to how best to deal with topics of violence and sexual abuse before assigning the text and even make resources available to students.

The book is full of discussion opportunities and many themes to explore. The story provides the opportunity to talk about social and sexual identity formation and finding one's place in the world. The role of religion also comes into play. Is it acceptable to follow certain mandates just because religion dictates it, even if those mandates are discriminatory? Males and females are clearly different in the society that the story paints, and this offers a great opportunity to discuss equality and gender roles in today's society. The role of parents can also be explored. What is good or bad parenting, and should parents put their own concerns ahead of what is best for their children? Finally, the novel even allows for a discussion about the increasing influence of Western ideals in the world. Saba' borderline obsession with American media is shared by many non-Westerners today; is this healthy for those that have completely different lifestyles? Is Western media enhancing, destroying, or having no effect at all on other cultures and traditions? These are all deep discussions that can arise from Nayeri's content-rich novel.

A recommendation to further student engagement and understanding of the novel is the use of a glossary that can help students bridge the cultural gap that a text like Nayeri's can create. Such a glossary should be either distributed to students along with the book or be made available online, as costs permit. Throughout the novel, Nayeri uses foreign terms that will likely be unknown to most students. Terms such as mullah, pasdar, chador, khanom, bazi, khastegari and dallak are used throughout the text, and giving students easy access to the meaning of these terms will enhance their understanding of the material. While students are capable of searching for these terms on their own, providing the list ensures that students will learn these terms and receive the correct definition. Students will also be more immersed and invested in the story. Invested students will make any educational programs based on this novel more meaningful. 
This novel is full of opportunities for interdisciplinary collaborations. The narrative has the Islamic revolution of 1979 in Iran as a background. The story shows the changes to daily life and the effects of the revolution, particularly on the Hafezi's lives. The narrative, however, does not elaborate on the revolution itself, the reasons behind it, the greater effect on the population and the country, and other relevant areas. The history department can provide more background context to the story by creating a seminar that would explain the revolution in more detail. Using the story as a connection, the revolution can be explained and probably linked to current world events relating to the so-called Arab Spring. The novel provides a unique opportunity to make history more relatable and palpable to students that have connected to the characters.

Religion plays a heavy role in A Teaspoon of Earth and Sea as well. The characters in it, particularly the women, struggle to comply with the new Islamic rules while living their daily lives. This presents another opportunity where the Islamic religion can be further explained. This could probably be done by the history department as well, or religious studies where available. Nayeri's work is the perfect opportunity to discuss Islam outside of the now ubiquitous terrorism spin given to it in the media. The rich traditions of Islam can be explained, giving context to many of the struggles that arise in the books that are directly connected to Islamic law.

Overall, I highly recommend this book be used as a first-year reading text. The many topics that are dealt with in this book make it relatable and informative at the same time. The usual teenage struggles will make the characters relatable, while the most likely foreign setting will show students that even those who come from different cultural and religious backgrounds from themselves also struggle with similar issues. This book shows a strong character struggling with the cards that destiny has dealt her, a character that doesn't give up on her dreams and fights for them despite their cost and consequences. It is a great book for incoming freshmen who will be dealing with similar issues such as life transitions, finding one's true career calling, learning to make decisions on one's own and live with the consequences, and properly channeling rebellious sentiments into constructive enterprises. 